\title{
Growth Performance of Clarias gariepinus (Buchell 1822) Fed Varying Inclusion Levels of Cassava Flour
}

\section{EZEAFULUKWE C.F. ${ }^{1 *}$, ONUOHA L.C. ${ }^{1}$ and AHAOTU E.O. ${ }^{2}$}

${ }^{* 1}$ Department of Fisheries and Aquaculture Technology, Federal University of Technology Owerri, Imo State, Nigeria.

${ }^{2}$ Department of Animal Production and Health Technology, Imo State Polytechnic Umuagwo, Nigeria.

Article No.: 081417104

Type: Research

DOI: 10.15580/GJBS.2017.5.081417104

Submitted: $14 / 08 / 2017$

Accepted: $24 / 08 / 2017$

Published: 14/10/2017

${ }^{*}$ Corresponding Author

Ezeafulukwe C.F.

E-mail: emmaocy@yahoo.com
This research was carried out to determine the dietary inclusion of cassava flour on growth performance of Clarias gariepinus fingerlings. Fifteen plastic containers were used and ten Clarias gariepinus fingerlings with mean weight $(2.29 \pm 0.08 \mathrm{~g})$ were randomly distributed into each of the plastic container. Four treatments were fed diets containing $40 \%$ crude protein with varying levels of cassava flour as carbohydrate source against yellow maize except the control ( $\left.\mathrm{T}_{0}\right)$ where cassava flour was not included. Diet $T_{1}$ contain $25 \%$ inclusion levels, $T_{2}$ $50 \%, \mathrm{~T}_{3} \mathbf{7 5} \%$ and $\mathrm{T}_{4} \mathbf{1 0 0} \%$ inclusion levels of the experimental diets respectively. Results showed that fish fed with diet $T_{3}$ had the best specific growth performance of $(2.63 \pm 0.01)$ and weight gain of $(7.49 \pm 0.76)$ being significantly different $(p<0.05)$ with other treatments including the control $(2.60 \pm 0.09)$. The weight gain of $\mathrm{T}_{3}(7.49 \pm 0.76)$, feed conversion ratio $(1.67 \pm 0.27)$ and protein efficiency ratio $(11.62 \pm 0.01)$ were significantly different $(p<0.05)$ with the control and favourable when compared with other diets.

Keywords:

Growth Performance, Clarias

gariepinus fingerlings, Cassava flour,

Carbohydrate, Feed conversion ratio

and Protein efficiency ratio 


\section{INTRODUCTION}

Protein sparing action of non-protein nutrients such as carbohydrates can effectively reduce feed costs (Shiau, 1997). Food is a key factor for all living organism including fish for reproduction, growth and maintenance. Evaluation of carbohydrate to minimize the high cost of protein, demand for man and animal response which (FAO, 2006) reported that aquaculture production has increased at an average of about $13-14 \%$ annually from 1970-2012. All over the world, aquaculture has become the fastest growing food production sector of the world with an average annual increase of about 10\% since 1984 when compared with 3\% increase for livestock meat and $1.6 \%$ increase for capture fisheries (FAO, 1997). To sustain such a high rate in aquaculture production, a similar increased level of fish feed production is required.

Fish is a major constituent source of human protein source in many tropical and sub-tropical countries (Ezeafulukwe et al., 2013). In order to maintain such a high rate of growth and effective production, there is need to develop cost effective and good quality feeds. Fish meal covers a major proportion of diet to fulfill the demand of protein (Tacon and Metian, 2008). The major problems confronting the fish farming industry are the increasing cost and inadequate supply of fish meal and the competition of other livestock industries for fish meal (Siddhuraja and Becker, 2003 and Ali et al., 2005). Due to the high cost of fish meal, its fluctuating quality and uncertainty on the availability which is the principal protein source in fish feed, it has become necessary to spare protein using carbohydrate of different sources such as corn starch, wild cocoyam corm (Ahaotu et al., 2013), cocoyam tubers, unripe plantain peel (Uwalaka et al., 2013), sweet potato tuber (Ahaotu et al., 2011, 2012), yam tubers, cassava tubers (Ahaotu et al., 2009) and cassava starch. The availability and non-competition of these carbohydrate energy sources with protein sources in livestock and human consumption, as well as industrial use make their cost more affordable and put them within the reach of fish farmers (Fasakin et al., 1999).

Modalities to lower the high cost of protein demand and its competition between livestock, aquatic animal and man posited that when carbohydrates are incorporated in fish diet, it will increase fish yield, meet market target as well as to reduce the high cost of feed. This will further enhance the feed pelletability since carbohydrate can be effectively utilized by fish including Clarias gariepinus.

\section{MATERIALS AND METHODS}

\section{Study area}

Owerri the capital city of Imo State, Nigeria lies within latitude $06^{\circ} 2906 \mathrm{~s}$ and longitude $07^{\circ} 02$ 06s. The area experiences a longer wert season which lasts from April to November than dry season which last for the rest of the year. It has mean daily maximum temperature range of $28^{\circ} \mathrm{C}$ to $35^{\circ} \mathrm{C}$, while daily minimum values ranges from $19^{\circ} \mathrm{C}$ to $24^{\circ} \mathrm{C}$, with average humidity of $80 \%$. The vegetation is dominated by semi-deciduous forest that has already been altered by agricultural and other anthropogenic activities and the dominant topsoil is moderately humus in composition.

The study was carried out in the Fisheries and Aquaculture Research Farm of the Federal University of Technology Owerri, Nigeria which provided the farmraised specimens used for the study. It is bounded by longitudes of $65^{\circ} 8^{\prime \prime} \mathrm{E}-7^{\circ}$ O3E and latitudes of $5^{\circ} 20^{\prime} \mathrm{N}-$ $5^{0} 28^{\prime} \mathrm{N}$. The institution has an annual rainfall between $192-194 \mathrm{~cm}$ and temperature of $32.18^{\circ} \mathrm{C}$.

\section{Experimental Procedure}

Diets with different inclusion levels of cassava flour at $0 \%, 25 \%, 50 \%, 75 \%$ and $100 \%$ were formulated. A total of 150 fingerlings of Clarias gariepinus collected from a commercial hatchery with a mean weight $3.00 \pm 0.06 \mathrm{~g}$ were used for the study. The fish were held inside 15 (fifteen) plastic containers each having 10 (ten) Clarias gariepinus fingerlings which were randomly distributed into each of the plastic container. Fish were allowed to acclimatize for a period of 7 days before the commencement of the experiment and were starved for 24 hours to empty their gastro intestinal tract.

Each diets was assigned to a group of ten (10) Clarias gariepinus fingerlings in triplicate, fish were fed twice daily in the morning hours (8am -9.30am) and in the evening hours (4pm $-5.30 \mathrm{pm})$ respectively.

Fish inside the 15 plastic containers were weighed simultaneously in batches at the end of every two weeks using digital weighing balance and return to their respective enclosures. The feed were adjusted every two weeks when the new mean weight of fish for the experiment were determined, unconsumed feed were siphoned out each week, stale water were renewed in the containers after 3 days from a bore hole at the farm unit. The experimental containers were monitored daily to remove mortality while physic chemical parameters were monitored for temperature, dissolved oxygen, ammonia, $\mathrm{P}^{\mathrm{H}}$ and hardness throughout the duration of the experiment for 56 days.

\section{Analysis of Fish samples for nutrient composition}

Samples were analyzed chemically in accordance (AOAC, 2005).

\section{Crude protein determination}

Crude protein was determined in accordance with AOAC (2005). The crude protein in the sample was determined by the routine semi micro Kjeldahl, procedure and 
technique. This consists of three techniques of analysis, namely, digestion, distillation and titration.

\section{Statistical analysis}

The two sets of data on nutrient composition emanating from fish were subjected to analysis in accordance with DNMRT (Gordon and Gordon, 2014).

\section{RESULTS}

Table 1-3 presents the gross composition of the experimental diet, proximate analysis of Claris gariepinus fingerlings and proximate analysis of experimental diets as evaluated. A total of five parameters were considered including crude protein, crude fat, crude fibre, ash and moisture

Table 1: Shows the Gross Composition of the Experimental Diet

\begin{tabular}{llllll}
\hline Ingredients & $\mathrm{T}_{0}$ & $\mathrm{~T}_{1}$ & $\mathrm{~T}_{2}$ & $\mathrm{~T}_{3}$ & $\mathrm{~T}_{4}$ \\
& $0 \%$ & $25 \%$ & $50 \%$ & $75 \%$ & $100 \%$ \\
\hline Fish meal & 33.94 & 25.47 & 16.97 & 8.49 & 33.94 \\
Soybean meal & 33.96 & 33.96 & 33.96 & 33.96 & 33 \\
Yellow maize & 19.85 & 14.89 & 9.93 & 4.96 & 0.00 \\
Cassava flour & 0.00 & 4.96 & 9.93 & 14.89 & 19.85 \\
Wheat bran & 5.00 & 5.00 & 5.00 & 5.00 & 5.00 \\
Fish meal & 1.50 & 1.50 & 1.50 & 1.50 & 1.50 \\
Vitamin C & 0.50 & 0.50 & 0.50 & 0.50 & 0.50 \\
Cod-liver Oil & 1.00 & 1.00 & 1.00 & 1.00 & 1.00 \\
Lysine & 0.25 & 0.25 & 0.25 & 0.25 & 0.25 \\
Methionine & 0.25 & 0.25 & 0.25 & 0.25 & 0.25 \\
Palm Oil & 1.00 & 1.00 & 1.00 & 1.00 & 1.00 \\
Common Salt & 0.25 & 0.25 & 0.25 & 0.25 & 0.25 \\
Corn Starch & 1.00 & 1.00 & 1.00 & 1.00 & 1.00 \\
Bone Meal & 1.50 & 1.50 & 1.50 & 1.50 & 1.50 \\
Total & 100.00 & 100.00 & 100.00 & 100.00 & 100.00 \\
\hline
\end{tabular}

Table 2: Proximate Analysis of Claris Gariepinus fingerlings as Evaluated

\begin{tabular}{lllllll}
\hline Parameters & Initial & $\mathrm{T}_{0}$ & $\mathrm{~T}_{1}$ & $\mathrm{~T}_{2}$ & $\mathrm{~T}_{3}$ & $\mathrm{~T}_{4}$ \\
\hline Moisture & 63.29 & 63.50 & 63.13 & 62.70 & 60.70 & 61.31 \\
C. Protein & 19.60 & 19.80 & 20.40 & 20.70 & 21.90 & 20.10 \\
Ash & 21.46 & 1.84 & 1.99 & 2.04 & 2.71 & 2.69 \\
Fat & 0.48 & 21.85 & 21.93 & 22.40 & 24.10 & 23.24 \\
Fibre & 0.01 & 0.10 & 0.18 & 0.18 & 0.20 & 0.13 \\
\hline
\end{tabular}

Table 3: Proximate Analysis of Experimental Diets

\begin{tabular}{llllll}
\hline Parameters & $\mathrm{T}_{0}$ & $\mathrm{~T}_{1}$ & $\mathrm{~T}_{2}$ & $\mathrm{~T}_{3}$ & $\mathrm{~T}_{4}$ \\
\hline Moisture & 10.80 & 10.20 & 10.40 & 10.00 & 10.64 \\
Ash & 0.36 & 0.40 & 0.42 & 0.38 & 0.40 \\
Fat & 4.80 & 5.12 & 5.18 & 5.16 & 5.12 \\
Fibre & 0.10 & 1.20 & 1.18 & 1.20 & 0.12 \\
Crude Protein & 40.0 & 40.01 & 40.05 & 40.08 & 40.05 \\
Carbohydrate & 74.92 & 74.88 & 74.82 & 74.66 & 75.70 \\
\hline
\end{tabular}


Table 4: Growth Performance of Experimental Fish

\begin{tabular}{llllll}
\hline Parameters & \multicolumn{1}{c}{$\mathrm{T}_{0}$} & $\mathrm{~T}_{1}$ & $\mathrm{~T}_{2}$ & $\mathrm{~T}_{3}$ & $\mathrm{~T}_{4}$ \\
\hline Initial weight gain $(\mathrm{g})$ & $2.18 \pm 0.12$ & $2.30 \pm 0.57$ & $2.29 \pm 0.08$ & $2.24 \pm 0.30$ & $2.22 \pm 0.01^{\mathrm{ns}}$ \\
Final weight gain $(\mathrm{g})$ & $4.78 \pm 0.14^{\mathrm{a}}$ & $7.22 \pm 0.90^{\mathrm{b}}$ & $7.49 \pm 0.08^{\mathrm{b}}$ & $9.73 \pm 0.10^{\mathrm{c}}$ & $4.88 \pm 0.04^{\mathrm{a}^{*}}$ \\
Weight gain (g) & $2.60 \pm 0.09^{\mathrm{a}}$ & $4.92 \pm 0.31^{\mathrm{b}}$ & $5.18 \pm 0.74^{\mathrm{b}}$ & $7.49 \pm 0.76^{\mathrm{c}}$ & $2.66 \pm 0.03^{\mathrm{a}^{*}}$ \\
Daily weight gain (g) & $0.05 \pm 0.01^{\mathrm{a}}$ & $0.08 \pm 0.01^{\mathrm{b}}$ & $0.09 \pm 0.01^{\mathrm{b}}$ & $0.13 \pm 0.02^{\mathrm{c}}$ & $0.05 \pm 0.01^{\mathrm{a}^{*}}$ \\
Specific growth rate & $1.40 \pm 0.06^{\mathrm{a}}$ & $2.04 \pm 0.02^{\mathrm{b}}$ & $2.12 \pm 0.05^{\mathrm{b}}$ & $2.63 \pm 0.01^{\mathrm{c}}$ & $1.41 \pm 0.01^{\mathrm{a}^{*}}$ \\
Feed conversion ratio & $2.80 \pm 0.01^{\mathrm{a}}$ & $2.08 \pm 0.31^{\mathrm{a}}$ & $2.79 \pm 0.02^{\mathrm{a}}$ & $1.67 \pm 0.27^{\mathrm{b}}$ & $2.80 \pm 0.67^{\mathrm{a}^{*}}$ \\
Percentage weight gain & $119.0 \pm 7.44^{\mathrm{a}}$ & $214.27 \pm 4.14^{\mathrm{b}}$ & $2^{\mathrm{b}}$ & $226.89 \pm 8.96^{\mathrm{b}}$ & $334.57 \pm 2.80^{\mathrm{c}}$ \\
$121.56 \pm 1.20^{\mathrm{a}^{*}}$ & & & & \\
Feed intake & $19.10 \pm 0.01^{\mathrm{a}}$ & $24.39 \pm 0.02^{\mathrm{b}}$ & $25.05 \pm 0.02^{\mathrm{b}}$ & $29.04 \pm 0.03^{\mathrm{c}}$ & $19.61 \pm 0.01^{\mathrm{a}}$ \\
Protein intake & $5.64 \pm 0.01^{\mathrm{a}}$ & $9.76 \pm 0.01^{\mathrm{b}}$ & $10.02 \pm 0.02^{\mathrm{b}}$ & $11.62 \pm 0.03^{\mathrm{b}}$ & $5.84 \pm 0.01^{\mathrm{a}^{*}}$ \\
Protein efficiency ratio & $0.34 \pm 0.10^{\mathrm{a}}$ & $0.61 \pm 0.01^{\mathrm{b}}$ & $0.52 \pm 0.01^{\mathrm{b}}$ & $0.64 \pm 0.61^{\mathrm{b}}$ & $0.37 \pm 0.31^{\mathrm{a}^{*}}$ \\
Nitrogen metabolism & $39.97 \pm 24.34^{\mathrm{a}}$ & $75.68 \pm 0.49^{\mathrm{b}}$ & $79.68 \pm 1.12^{\mathrm{b}}$ & $113.82 \pm 1.60^{\mathrm{c}}$ & $40.84 \pm 0.43^{\mathrm{a}^{*}}$ \\
Survival & $86.67 \pm 3.33^{\mathrm{a}}$ & $90.67 \pm 3.33^{\mathrm{b}}$ & $93.33 \pm 3.33^{\mathrm{b}}$ & $93.34 \pm 3.33^{\mathrm{b}}$ & $86.67 \pm 3.32^{\mathrm{a}^{*}}$ \\
\hline Mean
\end{tabular}

Mean on the same row having different superscripts are significantly different.

The cassava flour used in this study was said to have undergone processing technique to yield into powdered form as (FAO, 1997 and Booth et al., 2001) reported that processing conditions have great impact starch digestibility of fish in formulated diets.

Starch or dextrin is consumed more efficiently by catfish than sugars such as glucose or sucrose as it was postulated by (Shiau, 1997; Edwing and Meng, 1996). In this research, assertion made available revealed that there was significant difference in the body composition in protein efficiency ratio and percentage weight gain. Similar results found in another study revealed increase in high lipid content in the fish due to availability of sufficient energy with increasing levels of carbohydrate as conducted by (Anderson et al., 1984 ; Erfanullah and Jafri, 1995).

Better growth rate observed in $T_{3}$ of this experiment can be attributed to the ability of Clarias gariepinus fingerlings to utilize effectively the high level of carbohydrate provided relative to $T_{1}, T_{2}$ but exceptional to $T_{4}$ respectively as this was in relation to earlier works of (Wilson, 1987) who reported that channel catfish (Ictalurus puntatus) being a fresh water fish basically in temperate region were able to utilize over $70 \%$ of corn starch as carbohydrate and energy sources in the formulated diets. The research also contradicts the findings made by (Robinson and $\mathrm{Li}$, 1996) which stated that the optimum carbohydrate requirement for African fresh water catfish (Clarias gariepinus) was in the ranges of $25-35 \%$ ) inclusion levels.

\section{CONCLUSION}

Carbohydrate inclusion in diets of Clarias gariepinus favours growth performance feed conversion ratio, protein efficiency ratio and survival rates. The inclusion of carbohydrate sources in the diets of fish improved the growth of channel catfish but up to $100 \%$ inclusion level, growth rates will be reduced drastically.

\section{REFERENCES}

Ahaotu, E.O, Uwalaka, R.E and Ayo - Enwerem, C.M (2013). Enhancing Maize Stover utilization by West African Dwarf Sheep using Moringa Oleifera. Inter J Agri Biosci, 2(4): 153-155.

Ahaotu, E.O, Edih,M.C, Onuruka, A.U, Ehirim, V.I. and A. Sirimongkolkasen (2012). Effects of replacement of soyabean (Glycine max) with pigeon pea (Cajanus cajan) in starter broiler ration. International Journal of Tropical Agricultural and Food Systems. 6(1): $40-44$.

Ahaotu, E.O, Ogbuokiri,U.D.E, Korie, A.U, Ekenyem, B.U, Onwuka,C.F.I, Okoli, I.C, Peace .O. Njoku, Ndubuisi, E.C and F.N. Madubuike (2011). Effects of graded levels of pigeon pea meal on growth performance and Organ Characteristics of finisher broilers. Animal Production Research Advances. 7(2): $125-129$

Ahaotu, E.O, Karsten, K., Peace.O.Njoku, Yang, N., Ekenyem, B.U, Korie, A.U. and F.N. Madubuike (2009). Effects of partial replacement of Soya bean meal with cassava meal in broiler finisher rations. Animal Production Advances, 5(4): 295 - 299.

Ali, M., Iqbal, F., Salam, A., Iram, S and Athar, M. (2005). Comparative study of body composition of different fish species from brackish water pond. Int . J. Environ. Sci. Technol. 2:229-232.

Anderson, J., Jackson, A.J. Matty, J.A and Capper, B.S (1984). Effects of dietary carbohydrate and fiber on the tilapia (Oreochromis niloticus). Aquaculture $37: 303-314$.

AOAC (2005). Association of Official Analytical Chemist. Official Method of Analysis. W ashinton D.C. pp 146.

Booth, M.A., Allan,G.L., Franco, J and Parkinson, R (2001). Replacement of fish meal diets for Australian Silver Perch, Bidyanus bidyanus. Aquaculture 6: 67 -85 . 
Edwing, H.R and Meng, H.L (1996). A practical guide to Nutrition, Feeds and Feeding of Catfish. Blackwell Synergy Publishing Inc. 98-117 pp.

Erfanullah, M.N and Jafri, A.K. (1998). Effect of dietary carbohydrate to lipid ratio on growth and body composition of walking catfish (Clarias batrachus). Aquaculture 161:159 - 168).

Ezeafulukwe,C.F, Ahaotu, E.O, Madubuike,F.N and L.E Osuagwu (2013). Effect of Fertilization of Fish Pond with Graded Levels of Pig Dung on the Performance of Clarias gariepinus (Cat Fish) raised under Tropical Conditions. Inter J Appl Sci Engr, 1(1): 3136.

FAO, (1997). Review of the World Aquaculture. FAO Fisheries Circular. No. 886, S Review 1. Rome, Italy.

Gordon, S. P and Gordon, F. S (2014). Contemporary Statistics: A computer Approach. Mc.Graw - Hill Publishers, U.S.A. pp $98-112$.

Robinson, E.H and Li, M.H (1996). A practical guide to Nutrition, Feeds and Feeding of Catfish. Mississippi Aqucultural and Forestry Experiment Station. Mississippi State University, U.S.A. pp 67 -90.
Shiau, S.Y (1997). Utilization of Carbohydrates in warm water fish with particular reference to Tilapia, Oreochromis niloticus $\mathrm{x}$ Oreochromis aureus. Aquaculture, 151: 79-96.

Siddhuraja, P and Becker, K (2003). Comparative nutritional evolution of differentially processes mucuna seeds (Mucuna pruiens (Li) Dc. Var. utilis (Wallex Weight) Baker ex Bucck) on growth performance, feed utilization and body composition in Nile Tilapia (Oreochromis niloticus .L.) Aqacult. Res. 34:487-500.

Tacon, A.G.J and Metian, M (2008). Global overview of the use of Fish meal and Fish oil in Industrially compounded aqua feeds: Trends and future prospects. Aquaculture, 285: 146-158.

Uwalaka, R.E, Ihezuo, J.P and E.O.Ahaotu (2013). Effects of Inclusion of Unripe Plantain Peel Meal (Musa paradisca) on Carcass Quality, Performance and Internal Organ Weights in Finisher Broiler Birds. Inter J Agri Biosci, 2(4): 136-140

Wilson, R.P (1987). Apparent inability of channel catfish to utilize dietary mono and disaccharides as energy sources. The Journal of Nutrition. 117: $280-285$. 